\title{
Mengukur Tingkat Toleransi Pemuda Muslim di Kota Surabaya
}

\author{
Feryani Umi Rosidah,S.Ag,M.Fil.I \\ Universitas Islam Negeri Sunan Ampel Surabaya \\ Email: feryani66@gmail.com
}

\begin{abstract}
Surabaya is a multicultural city which consists of different communities, religions, and ethnics. However, the city has persisted to build harmonious relation between peoples. Based on Muslim-majority population, the city attempts to cultivate inter-religious solidarity and understanding among the people. Known that political, economic, and religious matters could influence people's behaviour, this research aims to see how the Muslim youth in the city understand and implement the social patterns of inter-religious relation. Using questionnaire method, the research found that $12.2 \%$ of the Muslim youth in Surabaya were very tolerant, $26.1 \%$ were tolerant, $28.9 \%$ were quite tolerant, $19.7 \%$ were intolerant, and $13.1 \%$ were very intolerant. This research also found that there are several factors influencing perceptions of Muslim youth in Surabaya for maintaining inter-religious tolerance, such as religion, politics, and social media.
\end{abstract}

[Surabaya merupakan wilayah yang terdiri dari beragam suku, agama dan budaya. Meskipun terdiri dari beragam suku agama dan budaya, masyarakat Surabaya dapat menjaga kerukunan antarumat beragama dengan baik. Perbedaan agama dan budaya bukan merupakan penghalang bagi 
masyarakatnya untuk menjaga persatuan dan kesatuan. Meski demikian, masih terjadi beberapa konflik lintas agama di Surabaya. Sebagai kota dengan penduduk mayoritas Muslim, warga Muslim Surabaya sejatinya menjaga solidaritas dan rasa saling menghormati, merangkul dan menjaga hak-hak sesama. Persoalan politik, ekonomi, dan agama memberikan pengaruh pada pemahaman dan cara pandang pemuda muslim dalam memaknai hubungan antarumat beragama. Untuk itu, perlu diketahui sejauh mana tingkat pemahaman pemuda Muslim dalam memahami hubungan toleransi antarumat beragama. Penelitian ini menggunakan metode kuantitatif, dengan menggunakan kuesioner yang disebarkan pada sampel yang sudah ditentukan. Dari hasil kajian di lapangan ditemukan bahwa $12,2 \%$ pemuda muslim Surabaya masuk dalam kategori sangat toleran, 26,1\% toleran, 28,9\% cukup toleran, $19,7 \%$ tidak toleran, dan $13,1 \%$ sangat tidak toleran. Ada beberapa faktor yang memengaruhi persepsi pemuda muslim dalam memahami toleransi antarumat beragama, yakni faktor paham keagamaan, politik agama, dan media sosial.]

Keywords: inter-religious relation, tolerance, intolerance, political identity, youth.

\section{Pendahuluan}

Isu radikalisme dan intoleransi menjadi isu yang mendapat perhatian khusus dari berbagai pihak. Hal ini tidak lepas dari semakin berkembangnya paham radikal serta tindakan intoleran dalam kehidupan bermasyarakat. Direktur eksekutif Wabid Institute, Yenny Wahid, pada tahun 2017 mengatakan bahwa survei-survei nasional yang dilakukan selama ini menemukan fakta adanya peningkatan paham radikal di Indonesia. ${ }^{1}$ Yenny menyebutkan bahwa $0,4 \%$ dari penduduk Indonesia

\footnotetext{
${ }^{1}$ Survei di atas dilakukan oleh tim Wabid Institut kepada 1.520 responden dengan model metode multi stage random sampling. Data dari Wabid Institute yang disampaikan oleh direktur eksekutif Yenny Wahid di Hotel Crowne Plaza tahun 2017, seperti dikutip oleh Republika.co.id

Http://-
} 
pernah melakukan tindakan radikal. Sementara responden yang berusia 17 tahun terindikasi punya potensi melakukan tindakan radikal. Perkiraan yang terburuk ke depan, kelompok ini mencapai angka 7,7\% dari penduduk Indonesia, atau setara dengan 11 juta. Berdasarkan survei tersebut, radikalisme dan tindakan intoleran memerlukan penanganan yang serius dari berbagai pihak karena penyebarannya sudah pada tingkat remaja yang menjadi tulang punggung masa depan bangsa Indonesia. Beberapa upaya sudah pernah dilakukan oleh organisasi Islam moderat untuk mencegah penyebaran paham radikal, akan tetapi penanganan yang lebih komprehensif disertai dengan dukungan berbagai pihak harus lebih ditingkatkan.

Data terbaru disampaikan oleh kepala BIN (Badan Intelijen Negara), Budi Gunawan, dalam pidatonya pada acara temu BEM-PTUN se-Indonesia di kampus Universitas Wahid Hasyim Semarang. Ia menjelaskan bahwa riset yang dilakukan oleh lembaganya pada tahun 2017 menghasilkan temuan sebanyak 39\% mahasiswa di Indonesia terpapar paham radikalisme. Lebih lanjut lagi dijelaskan 24\% mahasiswa dan 23,3\% siswa SMA sederajat setuju terhadap terbentuknya Negara Islam Indonesia (NII). ${ }^{2}$ Menurut Budi Gunawan, mahasiswa sering kali menjadi sasaran penyebaran paham radikalisme. Mereka menjadi target cuci otak untuk direkrut menjadi bagian dari jaringan teroris. ${ }^{3}$

Fakta di atas mengindikasikan bahwa paham radikalisme menjadi tantangan tersendiri bagi bangsa ini, untuk segera dicarikan solusi. Hal ini

nasional.republika.co.id/berita/nasional/umum/17/03/27/onh8yv366-yenny-wahidradikalisme-di-indonesia-meningkat, (diakses tanggal 7 Maret 2018).

2 Baca tulisan Mahfud MD dalam makalahnya pada seminar Annual Conference of Islam Scholar 2018 dengan tema "Memperkuat Islam Moderat" di Twin Tower UIN Sunan Ampel Surabaya. Ia menjelaskan, bahwa sejarah perjuangan untuk melandaskan Indonesia pada negara Islam sudah dilakukan sejak lama oleh beberapa founding fathers kita yang pro-Islam, akan tetapi sikap dan ide tersebut berseberangan dengan kelompok liberal yang menginginkan sebaliknya. Setelah diskusi panjang, disepakatilah Pancasila sebagai dasar negara dalam kehidupan bernegara di Republik Indonesia.

3 Budi Gunawan menambahkan bahwa saat ini ada tiga kampus di Indonesia yang sedang menjadi sorotan Badan Intelejen Negara karena dianggap menjadi pusat penyebaran paham radikal. Disampaikan oleh Budi Gunawan dalam acara temu BEMPTUN di Semarang tahun 2018. Seperti yang dikutip oleh https://news.detik.com/jawatengah/3995680/bin-3-universitas-diawasi-khusus-terkaitpenyebaran-radikalisme, (diakses tanggal 5 April 2018). 
penting, agar ia tidak terus menerus menghantui keutuhan NKRI. Dalam konteks ini, pemuda menjadi elemen masyarakat yang paling mudah menjadi sasaran oleh paham radikal bila tidak dibekali fondasi ilmu serta wawasan kebangsaan yang kuat. Oleh karenanya, perlu ada solusi kongkret untuk menghentikan penyebaran paham radikal di kalangan pemuda. Meningkatnya paham radikalisme berbanding lurus dengan jumlah tindakan intoleran yang terjadi di masyarakat. Hal ini disebabkan radikalisme cenderung memahami agama dengan sikap yang keras dengan dalih mengamalkan ajaran agamanya secara benar. ${ }^{4}$ Sejarah mencatat bahwa radikalisme model kekerasan dalam Islam sudah ada sejak zaman sahabat, yakni saat memuncaknya konflik pendukung sahabat Ali bin Abi Thalib dan pendukung Muawiyah. ${ }^{5}$

Pada Oktober 2017, Wahid Institute melalui direktur eksekutifnya, Yenny Wahid, menyampaikan laporan peningkatan potensi intoleransi terhadap kelompok yang tidak disukai oleh kaum muslimin sebesar 57,1\%. Survei yang dilakukan pada tahun 2017 tersebut mengambil sampel 1500 responden dari berbagai wilayah Indonesia. Hasil survei itu meningkat dari tahun sebelumnya, yakni sebesar 51,0\%. Dari total responden di atas ada sebanyak 13,2\% yang setuju dengan gerakan jihad menggunakan kekerasan. ${ }^{6}$

Data-data di atas menggambarkan bahwa tindakan intoleran dan pemahaman ajaran agama dengan menggunakan kekerasan mengalami peningkatan dari tahun sebelumnya, dan pemuda menjadi salah satu elemen masyarakat yang terpapar dan berpotensi melakukan tindakan intoleran. Mereka menjadi sasaran empuk bagi kelompok radikal untuk direkrut, diarahkan kepada pemahaman radikal, lalu dilejitkan potensinya untuk menciptakan tindakan intoleran. Artinya, pemuda yang sudah terpapar paham radikal akan cenderung melakukan tindakan intoleran,

\footnotetext{
4 Shobirin, "Interpretasi Paham Radikalisme Terhadap Hukum Islam," Jurnal ADDIN, Vol. 10 No. 1 tahun (2016), 109.

5 Syamruddin Nasution, Sejarah Peradaban Islam (Riau: Yayasan Pustaka, 2013), 90; Siti Maryam, Sejarab Peradaban Islam dari Klasik bingga Modern (Yogyakarta: LESFI, 2009), 56; Ahmad Syalabi, Sejarah dan Kebudayaan Islam (Jakarta: PT. Alhusna Zikra, 1997), 301. 6 Survei yang dilakukan oleh Wabid Institute pada bulan Oktober tahun 2017, dengan mengambil sampel responden sebanyak 1500 responden dari 34 provinsi di seluruh Indonesia, lihat juga di https://news.detik.com/berita/d-3839963/survei-potensiintoleransi-muslim-ri-meningkat-projihad-keras-13,(diakses tanggal 21 Januari 2018).
} 
bahkan berani melakukan kekerasan dalam menegakkan keyakinan radikalnya.

Penelitian ini hendak mengukur tingkat toleransi pemuda Muslim di Kota Surabaya, kota dengan komposisi penduduk yang beragam, ${ }^{7}$ baik dari sisi agama, suku, adat istiadat, dan budaya. Berdasarkan data statistik, jumlah pemuda di kota Surabaya sekitar 790.046 jiwa $^{8}$ dari jumlah keseluruhan penduduk sebanyak 2.848.583 jiwa. ${ }^{9}$ Oleh karena itu, kajian terhadap toleransi pemuda Muslim di kota Surabaya perlu dilakukan dengan berbagai landasan dan tujuan penting. Pertama, hal itu diakukan untuk memberi gambaran sosiologis terhadap sikap toleransi pemuda Muslim di kota Surabaya. Kedua, untuk memetakan dan mengukur sejauh mana tingkat toleransi pemuda muslim di kota Surabaya. Ketiga, sebab kajian tentang tingkat toleransi pemuda terasa masih sedikit dilakukan. Lebih dari itu, penelitian ini juga diharapkan bisa menjadi salah satu referensi pemerintah daerah dalam menentukan kebijakan.

\section{Toleransi Pemuda Muslim Surabaya}

Untuk mengukur tingkat toleransi pemuda Muslim di Surabaya, penelitian ini berangkat dari pertanyaan mendasar soal keberpihakan Islam terhadap toleransi. Ketika responden ditanya pendapatnya tentang

\footnotetext{
7 Data Badan Pusat Statistik Kota Surabaya menyebutkan, bahwa jumlah penduduk berdasarkan agama pada tahun 2014 adalah sebagai berikut: pemeluk Agama Islam 2.432.502 jiwa, Agama Katolik 116.703, Agama Kristen sejumlah 266.608, Agama Buddha sebanyak 45.150, Agama Hindu sebanyak 8.436, Agama Konghucu sebesar 389, dan lainnya sejumlah 171 jiwa. Sedangkan untuk suku di kota Surabaya setidaknya terdapat beberapa suku, diantarnya adalah suku Jawa 83,68\%, Madura 7,5\%, Tionghoa 7,25\%, Arab 2,04\%, serta selebihnya adalah berbagai suku lainnya seperti suku Bali, Batak, Bugis, Manado, Minangkabau, Dayak, Toraja, Ambon, Aceh dan warga asing. Lihat www.bpd.go.id (diakses tanggal 17 Januari 2018).

${ }^{8}$ Kategori pemuda adalah seseorang dengan usia 15-30 tahun. Lihat dalam Wahyu, Wawasan Ilmu Sosial Dasar (Surabaya: Usaha Nasional, 2006), 69-70. Dari kategori usia pemuda tersebut maka detail rincian di kota Surabaya adalah usia 15-19 tahun berjumlah 228.132 jiwa, 20-24 sejumlah 290.777 jiwa dan uisa 25-30 sejumlah 271.137 jiwa. Lihat di data Badan Pusat Statistik Kota Surabaya di kota Surabaya. www.bpd.go.id (diakses tanggal 10 Mei 2018).

${ }^{9}$ Data dari Badan Pusat Statistik Provinsi Jawa Timur pada tahun 2015, setiap tahunnya pertumbuhan penduduk di kota Surabaya selalu mengalami peningkatan. Setiap tahunnya peningkatan jumlah penduduk kota Surabaya mencapai 0,53\%. Dalam jatim.www.bps..go.id, (diakses tanggal 17 September 2017).
} 
pernyataan bahwa Islam menjunjung tinggi toleransi, bahwa Islam menghargai setiap perbedaan, baik perbedaan dalam agama ataupun budaya, terdapat $38 \%$ responden yang setuju sementara $62 \%$ responden sangat setuju.

Kenyataan bahwa agama Islam juga mengajarkan umatnya untuk selalu meyakini Islam sebagai ajaran yang paling benar dipahami responden sebagai sikap yang memang harus ada dan ditanamkan, tetapi ketika berhadapan dengan agama dan keyakinan lain yang berbeda, nilai dan sikap toleran harus ditonjolkan. Meyakini kebenaran agam sendiri tidak berarti tidak menghargai agama lain. Hal ini dilakukan sebagai upaya menjaga hubungan baik dengan pemeluk agama lain. Keyakinan ini menjadi jawaban umum dari responden terkait dengan Islam dan nilai toleransi.

Poin pertanyaan selanjutnya lebih menitikberatkan pada pandangan pemuda Muslim menyikapi kehidupan masyarakat yang plural. Penelitian ini mengajukan sebanyak 11 pertanyaan dengan 3 kategori sifat: sensitivitas yang rendah, sedang, dan tingkat sensitivitas yang tinggi. Pertanyaan detail dan contoh jawaban responden bisa dilihat di tabel berikut (lihat tabel 1).

Tabel 1

\begin{tabular}{|l|c|c|c|}
\hline Jenis pertanyaan & Rendah & Sedang & Tinggi \\
\hline $\begin{array}{l}\text { Apakah Saudara keberatan jika mempunyai tetangga } \\
\text { Non- Muslim }\end{array}$ & $\mathrm{X}$ & & \\
\hline $\begin{array}{l}\text { Apakah Saudara keberatan jika mempunyai sahabat } \\
\text { Non- Muslim }\end{array}$ & $\mathrm{X}$ & & \\
\hline $\begin{array}{l}\text { Apakah saudara keberatan jika ada tempat ibadah } \\
\text { Non- Muslim di lingkungan saudara }\end{array}$ & $\mathrm{X}$ & \\
\hline $\begin{array}{l}\text { Apakah saudara keberatan jika harus menjenguk } \\
\text { Non- Muslim yang sedang sakit }\end{array}$ & $\mathrm{X}$ & $\mathrm{X}$ & \\
\hline $\begin{array}{l}\text { Apakah saudara keberatan jika harus mengucapkan } \\
\text { Selamat Natal }\end{array}$ & & $\mathrm{X}$ & $\mathrm{X}$ \\
\hline $\begin{array}{l}\text { Apakah saudara keberatan jika menerima makanan } \\
\text { dari Non-Muslim }\end{array}$ & $\mathrm{X}$ & & \\
\hline $\begin{array}{l}\text { Apakah saudara keberatan menyumbangkan dana } \\
\text { untuk pembangunan tempat Ibadah Non- Muslim }\end{array}$ & & & $\mathrm{X}$ \\
\hline $\begin{array}{l}\text { Apakah saudara keberatan jika memakai produk } \\
\text { Non- Muslim }\end{array}$ & $\mathrm{X}$ & \\
\hline Apakah saudara keberatan jika harus menghadiri & & & \\
\hline
\end{tabular}




\begin{tabular}{|l|l|l|}
\hline $\begin{array}{l}\text { perayaan Natal di tempat umum (atau perayaan hari } \\
\text { besar Agama lain) }\end{array}$ & & \\
\hline $\begin{array}{l}\text { Apakah saudara keberatan untuk menghadiri acara } \\
\text { Misa Natal di Gereja (hari besar Agama lain) }\end{array}$ & & $\mathrm{X}$ \\
\hline $\begin{array}{l}\text { Apakah saudara keberatan jika mempunyai } \\
\text { pemimpin Non- Muslim }\end{array}$ & & $\mathrm{X}$ \\
\hline
\end{tabular}

Secara umum, semua jawaban dari responden mengamini dan meneguhkan sikap toleran terhadap realitas ke-bertetanggaan lintas agama, misalnya, sebagai wujud penghargaan terhadap pluralisme agama. Berikut rinciannya (lihat tabel 2):

Tabel 2

\begin{tabular}{|c|c|c|c|c|c|c|}
\hline Usia & $\begin{array}{c}\text { Sangat } \\
\text { tidak } \\
\text { keberatan }\end{array}$ & $\begin{array}{c}\text { Tidak } \\
\text { Keberatan }\end{array}$ & $\begin{array}{c}\text { Netral/ } \\
\text { biasa }\end{array}$ & Keberatan & $\begin{array}{c}\text { Sangat } \\
\text { keberatan }\end{array}$ & $\%$ \\
\hline $\begin{array}{l}19-23 \\
\text { tahun }\end{array}$ & 22 & 22 & 6 & & & \\
\hline $\begin{array}{l}15-18 \\
\text { tahun }\end{array}$ & 11 & 18 & 10 & & 1 & 100 \\
\hline $\begin{array}{l}24-30 \\
\text { tahun }\end{array}$ & 2 & 4 & 4 & & & \\
\hline Total & 35 & 44 & 20 & 0 & 1 & 100 \\
\hline
\end{tabular}

Tabel di atas menggambarkan dengan detail bahwa sebanyak 64 pemuda Muslim di Surabaya tidak keberatan dan 35 menjawab sangat tidak keberatan bertetangga dengan orang nonMuslim. Mayoritas pemuda Muslim Surabaya dalam survei ini masuk dalam dua kategori: sangat tidak keberatan dan tidak keberatan, membangun ketetanggaan dengan non-Muslim.

Lalu bagaimana dengan teman non-Muslim? Jawaban responden bisa dilihat dari tabel di bawah ini (lihat tabel 3).

Tabel 3

\begin{tabular}{|c|c|c|c|c|c|c|}
\hline Usia & $\begin{array}{c}\text { Sangat } \\
\text { tidak } \\
\text { keberatan }\end{array}$ & $\begin{array}{c}\text { Tidak } \\
\text { Keberatan }\end{array}$ & $\begin{array}{c}\text { Netral/ } \\
\text { biasa }\end{array}$ & Keberatan & $\begin{array}{c}\text { Sangat } \\
\text { keberatan }\end{array}$ & $\%$ \\
\hline $\begin{array}{c}19-23 \\
\text { tahun }\end{array}$ & 18 & 24 & 8 & 0 & & \\
\hline
\end{tabular}




\begin{tabular}{|l|c|c|c|c|c|c|}
\hline $\begin{array}{l}15-18 \\
\text { tahun }\end{array}$ & 10 & 20 & 8 & 0 & 2 & 100 \\
\hline $\begin{array}{l}24-30 \\
\text { tahun }\end{array}$ & 4 & 4 & 2 & 0 & & \\
\hline Total & $\mathbf{3 2}$ & $\mathbf{4 8}$ & $\mathbf{1 8}$ & $\mathbf{0}$ & $\mathbf{2}$ & $\mathbf{1 0 0}$ \\
\hline
\end{tabular}

Tabel di atas menunjukkan bahwa sebagian besar pemuda Muslim di kota Surabaya tidak keberatan memiliki teman non-Muslim. Sebanyak 48 responden menyatakan tidak keberatan dan 32 responden menjawab sangat tidak keberatan. Jawaban responden ini di atas mengemukakan fakta bahwa pemuda Muslim Surabaya bisa menghargai perbedaan agama yang mereka alami dalam lingkaran pertemanan. Teman non-Muslim bukanlah suatu masalah. Menurut salah satu responden, berteman dengan orang berbeda agama bukanlah sesuatu yang perlu dipermasalahkan, selama berteman masih dalam tahap yang wajar, tanpa membahas urusan teologi masing-masing agama. ${ }^{10}$

Poin pertanyaan selanjutnya adalah soal adanya tempat ibadah non-Muslim di lingkungan dan tempat tinggal mereka. Berbeda dengan poin-poin sebelumnya, pada poin ini ada 4 orang responden yang menjawab keberatan dan 2 orang menjawab sangat keberatan. Rata-rata usia dua kelompok ini adalah 15-18, usia pertengahan dari standar pemuda yang digunakan dalam penelitian ini. Sementara $43 \%$ responden mengatakan tidak keberatan, 16\% sangat tidak keberatan, dan sebanyak $35 \%$ menyatakan netral.

Ketiga ditanya perihal apakah keberatan atau tidak untuk menjenguk teman atau tetangga non-Muslim yang sedang sakit, rata-rata responden menjawab tidak keberatan. Hal ini selaras dengan jawaban atas poin-poin sebelumnya. Hal ini menjelaskan bahwa pemuda Muslim Surabaya menjunjung tinggi nilai humanisme dalam beragama. Mereka menegakkan apa yang disebut ukbuwwah bashariyah, hubungan kemanusian, dan menganggap hal itu penting dan harus dijaga tanpa perlu membeda-bedakan agama. Rincian survei berdasarkan jumlah seluruh responden pada masing-masing rentang usia menjelaskan bahwa pada rentang usia 19-23 tahun sebanyak 52\% menjawab sangat tidak

${ }^{10}$ Nuha Ufaira, Wawancara, Surabaya, 21 September 2018. 
keberatan, pada rentang usia 15-18 tahun sebanyak 48\% menjawab tidak keberatan, pada rentang usia 24-30 tahun 90\% menjawab tidak keberatan.

Menarik untuk melihat adanya keragaman jawaban responden ketika ditanya soal ucapan Selamat Natal kepada umat Kristen atau Katolik. Berbeda dari sebelumnya, mayoritas responden menjawab keberatan atas poin ini (lihat tabel 4).

Tabel 4

\begin{tabular}{|c|c|c|c|c|c|c|}
\hline Usia & $\begin{array}{c}\text { Sangat } \\
\text { tidak } \\
\text { keberatan }\end{array}$ & $\begin{array}{c}\text { Tidak } \\
\text { Keberatan }\end{array}$ & $\begin{array}{c}\text { Netral/ } \\
\text { biasa }\end{array}$ & Keberatan & $\begin{array}{c}\text { Sangat } \\
\text { keberatan }\end{array}$ & $\%$ \\
\hline $\begin{array}{c}19-23 \\
\text { tahun }\end{array}$ & 2 & 6 & 16 & 14 & 12 & 50 \\
\hline $\begin{array}{c}15-18 \\
\text { tahun }\end{array}$ & 1 & 6 & 8 & 15 & 10 & 42 \\
\hline $\begin{array}{l}24-30 \\
\text { tahun }\end{array}$ & 0 & 1 & 4 & 3 & 2 & 8 \\
\hline Total & $\mathbf{3}$ & $\mathbf{1 3}$ & $\mathbf{2 8}$ & $\mathbf{3 2}$ & $\mathbf{2 4}$ & $\mathbf{1 0 0}$ \\
\hline
\end{tabular}

Tabel di atas memperlihatkan bahwa mayoritas pemuda Muslim Surabaya memiliki sikap keberatan untuk mengucapkan Selamat Natal kepada pemeluk agama Kristen atau Katolik. Bahkan sebanyak 24\% menjawab sangat keberatan jika harus mengucapkan ucapan selamat tersebut. Dari temuan tersebut dapat dilihat bahwa pemahaman remaja pada usia 15-18 tahun masih labil terhadap berbagai isu-isu keagamaan yang berkembang di lingkungannya. Di satu sisi mereka tidak keberatan berteman dan bertetangga dengan non-Muslim, tetapi di sisi lain mereka merasa keberatan untuk mengucapkan Selamat Natal kepada nonMuslim. Ketika ditanya lebih lanjut apa penyebab keberatan tersebut, mereka merujuk kepada informasi media sosial dan sumber lain yang mengatakan bahwa mengucapkan Selamat Natal pada umat kristiani adalah haram. Hal ini menunjukkan bahwa media sosial sangat besar pengaruhnya terhadap pola pikir, pengetahuan dan tindakan pemuda Muslim. ${ }^{11}$

${ }^{11}$ Reza, Wawancara, Surabaya, 22 September 2018. 
Sikap terhadap ucapan Selamat Natal di atas tidak terlihat dalam poin "apakah mereka keberatan atau tidak menerima makanan pemberian non-Muslim." Sebanyak 44\% responden menjawab netral atau biasa saja. Penjelasan rinci dari persentase responden dalam poin ini sebagai berikut: rentang usia 19-23 tahun sebanyak 42\% menjawab netral atau biasa saja, rentang usia 15-18 tahun sebanyak 50\% merasa biasa saja, dan rentang usia 24-30 tahun terdapat sebanyak 30\% yang menjawab netral.

Jika poin sebelumnya berbicara tentang "menerima", maka pertanyaan lanjutannya adalah "memberi". Saat ditanya apakah responden keberatan jika harus menyumbangkan dana untuk pembangunan tempat ibadah non-Muslim, sebanyak 41\% responden menjawab biasa saja, sementara 30\% menjawab keberatan (lihat tabel 5).

Tabel 5

\begin{tabular}{|c|c|c|c|c|c|c|}
\hline Usia & $\begin{array}{c}\text { Sangat } \\
\text { tidak } \\
\text { keberatan }\end{array}$ & $\begin{array}{c}\text { Tidak } \\
\text { Keberatan }\end{array}$ & $\begin{array}{c}\text { Netral/ } \\
\text { biasa }\end{array}$ & Keberatan & $\begin{array}{c}\text { Sangat } \\
\text { keberatan }\end{array}$ & $\%$ \\
\hline $\begin{array}{c}19-23 \\
\text { tahun }\end{array}$ & 2 & 8 & 17 & 20 & 3 & 33 \\
\hline $\begin{array}{c}15-18 \\
\text { tahun }\end{array}$ & 0 & 8 & 21 & 6 & 5 & 56 \\
\hline $\begin{array}{l}24-30 \\
\text { tahun }\end{array}$ & 0 & 2 & 3 & 4 & 1 & 11 \\
\hline Total & $\mathbf{2}$ & $\mathbf{1 8}$ & $\mathbf{4 1}$ & $\mathbf{3 0}$ & $\mathbf{9}$ & $\mathbf{1 0 0}$ \\
\hline
\end{tabular}

Data di atas menjelaskan bahwa mayoritas remaja tingkat SMA menjawab biasa saja jika harus menyumbangkan dana untuk tempat ibadah non-Muslim, sedangkan di kalangan mahasiswa dan pekerja ada lebih banyak persentase yang merasa keberatan. Mungkin, ini juga disebabkan dengan konteks lapangan kerja dan status generasi yang berbeda.

Bagaimana dengan produk non-Muslim? Ketika mereka ditanya apakah keberatan menggunakan produk-produk yang diproduksi oleh orang non-Muslim, sebagian besar responden menjawab netral atau biasa saja. Secara detail penjelasan jawaban responden sebagai berikut: rentang usia 19-23 tahun sebanyak 42\% responden menjawab netral, rentang 
waktu 15-18 tahun sebanyak 53\% menjawab netral, dan rentang usia 2430 tahun sebanyak 40\% menjawab netral. Dari data tersebut bisa dilihat bahwa masyarakat pemuda Muslim di Surabaya cukup toleran terhadap penggunaan produk yang diproduksi oleh masyarakat non-Muslim.

Pertanyaan lanjutannya adalah soal keikutsertaan responden dalam perayaan Natal: apakah mereka merasa keberatan jika harus menghadiri perayaan Natal meskipun di tempat terbuka atau tempat umum? Mayoritas responden menjawab keberatan, dalam setiap jenjang usia. Detail dari jawaban responden bisa dilihat dari tabel berikut.

Tabel 6

\begin{tabular}{|c|c|c|c|c|c|c|}
\hline Usia & $\begin{array}{c}\text { Sangat } \\
\text { tidak } \\
\text { keberatan }\end{array}$ & $\begin{array}{c}\text { Tidak } \\
\text { Keberatan }\end{array}$ & $\begin{array}{c}\text { Netral/ } \\
\text { biasa }\end{array}$ & Keberatan & $\begin{array}{c}\text { Sangat } \\
\text { keberatan }\end{array}$ & $\%$ \\
\hline $\begin{array}{c}19-23 \\
\text { tahun }\end{array}$ & 1 & 5 & 16 & 21 & 7 & 35 \\
\hline $\begin{array}{c}15-18 \\
\text { tahun }\end{array}$ & 1 & 4 & 6 & 18 & 11 & 55 \\
\hline $\begin{array}{l}24-30 \\
\text { tahun }\end{array}$ & 0 & 0 & 5 & 3 & 2 & 10 \\
\hline Total & $\mathbf{2}$ & $\mathbf{9}$ & $\mathbf{2 7}$ & $\mathbf{4 2}$ & $\mathbf{2 0}$ & $\mathbf{1 0 0}$ \\
\hline
\end{tabular}

Sebagai kelanjutan dari poin di atas, pertanyaannya dibuat lebih spesifik. Bagaimana kalau perayaan Natal tersebut diadakan di gereja? Hampir seratus persen responden menjawab keberatan atau sangat keberatan dalam rentang usia yang berbeda. Dari tabel di atas dapat kita lihat bahwa mayoritas pemuda Muslim keberatan dan sangat keberatan untuk menghadiri acara natal di gereja dengan rincian sebagai berikut: pada rentang usia 19-23 tahun sebanyak $42 \%$ responden merasa keberatan, sebanyak 50\% responden pada rentang usia 15-18 tahun merasa keberatan, dan pada usia 24-30 tahun sebanyak 50\% responden merasa sangat keberatan. Sekali lagi, terdapat jarak dan lompatan yang beragam dari jawaban-jawaban yang diberikan responden antara satu poin dengan poin pertanyaan yang lainnya.

Poin pertanyaan terakhir untuk mengukur tingkat toleransi pemuda Muslim Surabaya dalam penelitian ini adalah soal "keberatan 
atau tidak mempunyai pemimpin non-Muslim.” Sebanyak 30\% dari responden menjawab sangat keberatan jika harus dipimpin oleh nonMuslim, sebanyak 28\% responden dan 27\% responden bersikap netral atau biasa saja. Adapun detail data jawaban responden berdasarkan rentang usia adalah sebagai berikut: pada rentang usia 19-23 tahun sebanyak 38\% responden merasa sangat keberatan, pada rentang usia 1518 tahun sebanyak 30\% responden menjawab keberatan, dan pada rentang waktu 24-30 tahun sebanyak 40\% responden merasa keberatan. Dari paparan data tersebut bisa diketahui bahwa mayoritas pemuda Muslim di Surabaya secara umum keberatan jika harus dipimpin oleh pemimpin non-Muslim. Pola pemahaman seperti ini tidak lepas dari info pengaruh politik identitas yang semakin menguat pasca Pilkada DKI. Bahkan, hingga saat ini info-info dan berbagai gerakan politik mengatasnamakan agama berlangsung hingga berjilid-jilid. Diperparah lagi dengan tingkah para elite politik yang cenderung memanfaatkan situasi tanpa memedulikan risiko terpecah belahnya persatuan dan kesatuan bangsa. ${ }^{12}$

\section{Penutup}

Dari paparan hasil penelitian dan jawaban responden di atas bisa disimpulkan temuan penelitian sebagai berikut: Pertama, 12,2\% pemuda Muslim di Surabaya masuk dalam kategori sangat toleran. Kedua, 26,1\% pemuda Muslim kota Surabaya masuk dalam kategori toleran. Ketiga, $28,9 \%$ pemuda Muslim kota Surabaya masuk dalam kategori cukup toleran. Keempat, 19,7\% pemuda Muslim kota Surabaya terindikasi tidak toleran. Kelima, 13,1\% pemuda Muslim kota Surabaya terindikasi sangat tidak toleran. Pertanyaan selanjutnya adalah: apa faktor yang mempengaruhi tingkat toleransi Pemuda Surabaya?

Ada beberapa faktor yang mempengaruhi tingkat toleransi dan intoleransi pada diri pemuda Muslim di kota Surabaya. Pertama, media sosial. Sebagai salah satu pengguna media sosial terbanyak, pemuda menjadi sasaran berbagai postingan dan publikasi yang terkadang dipertanyakan keabsahannya. Hoax menjadi salah satu penyebabnya.

${ }^{12}$ Dwi Cahyo, Wawancara, Surabaya, 15 September 2018. 
Mereka cenderung menelan mentah-mentah informasi yang mereka dapatkan.

Kedua, politik identitas. Menguatnya politik identitas yang terjadi dalam kontestasi politik nasional, diawali dengan politik identitas pada perhelatan Pilkada DKI Jakarta pada tahun 2017, berdampak pada fenomena politisasi agama. Di kalangan pemuda, politik identitas seperti ini terbukti mampu mempengaruhi sikap politik yang berdampak pada pilihan politik. Realitas ini berpengaruh pada respons dan jawaban pemuda Muslim terhadap survei dan poin pertanyaan dalam penelitian ini.

Ketiga, paham keagamaan. Latar belakang pendidikan pemuda Muslim juga memiliki pengaruh terhadap sikap mereka dalam membangun hubungan antar-agama. Sikap dan wawasan toleran atau tidak toleran bisa dipengaruhi oleh disiplin ilmu agama yang mereka pelajari. Pengetahuan menjadi modal penting untuk menumbuhkan sikap toleran di kalangan para pemuda.

\section{Daftar Pustaka}

Maryam, Siti. Sejarah Peradaban Islam dari Klasik hingga Modern. Yogyakarta: LESFI, 2009.

Nasution, Syamruddin. Sejarah Peradaban Islam. Riau: Yayasan Pustaka, 2013.

Shobirin. "Interpretasi Paham Radikalisme Terhadap Hukum Islam," jurnal ADDIN, Vol. 10 No. 1, tabun 2016.

Syalabi, Ahmad. Sejarah dan Kebudayaan Islam. Jakarta: PT. Alhusna Zikra, 1997.

Tim FKUB Semarang. Kapita Selekta Kerukunan Umat Beragama. Semarang: FKUB, 2009.

Tim Penyusun. Kamus Besar Bahasa Indonesia. Jakarta: Pusat Bahasa Departemen Pendidikan Nasional, 2008.

Wahyu. Wawasan Ilmu Sosial Dasar. Surabaya: Usaha Nasional, 2006.

Williams, Michael R dan Jackson, Aaron P. "A New Definiton of Tolerance." Issue in Religion and Psychoteraphy, Vol. 37 No. 1. 2015. 
Witenberg, R.T. “The Moral Dimension of Children's and Adolescents' Conceptualisation of Tolerance to Human Diversity." Jurnal Of Moral Education, Volume 36, 2007-Issue 4. https://doi.org/10.1080/03057240701688002

Zuhdi, Muhammad Harfin. "Fundamentalisme dan Upaya Deradikalisasi Pemahaman Al-Qur'an dan Hadist.” Jurnal Religia, Vol. 13 No. 1. 2010. 